Kuramsal Derleme

\title{
Klinik Bir Olgu Olarak Yalnızlık: Yalnızlık ve Psikolojik Bozukluklar
}

Hanife KAHRAMAN ${ }^{*}$

${ }^{1}$ Ege Üniversitesi, Eğitim Fakültesi, Eğitim Bilimleri Bölümü Rehberlik ve Psikolojik Danışmanlık Anabilim Dalı, İzmir, Türkiye

\section{Makale Bilgisi}

\section{Anahtar}

kelimeler:

yalnızlık, tek

başınalık,

psikolojik

bozukluklar

\section{$\ddot{O} \mathbf{z}$}

Yalnızlık, içinde bulunduğumuz yüzyılda, hızla değişen çevresel ve toplumsal koşullar nedeniyle her geçen gün daha fazla sorun haline gelmektedir. Yapılan araştırmalar yalnızlığın psikolojik bozukluklarla doğrudan ilişkili olduğunu göstermiştir. Psikolojik bozukluklarda yaşanan yalnızlık objektif olarak tanımlanabilmesine rağmen, deneyimin kendisinin sübjektif olmasından dolayı klinisyenler ve araştırmacılar tarafından bu deneyimin niteliğinin tanımlanması oldukça güçtür. Bu makalede, yardım almak amacıyla danışma merkezine başvuran vakalar üzerinden, psikolojik bozukluklarda yaşanan yalnızlığın niteliksel özellikleri ve kökenleri literatürdeki bilgiler ışı̆̆ında tartışılmıştır. Seçilen psikolojik bozukluklarda yalnızlık temel bir bulgudur ya da bozukluğu yaşadığı sürede, kişi yalnızlığı ciddi bir sorun olarak deneyimlemektedir. Belirlenen psikolojik bozukluklar şunlardır: şizofreni, sosyal kaygı bozukluğu, otizm spektrum bozukluğu borderline kişilik bozukluğu, narsistik kişilik bozukluğu, şizoid kişilik bozukluğu, çekingen kişilik bozukluğu ve bağımlı kişilik bozukluğu. Makalede sunulan vaka örnekleri, Belediye'ye bağlı kadın danışma merkezine yardım almak amacıyla başvuran ve tanı kriterlerini karşılayan danışanlar arasından rastgele seçilmiştir. Başvuran danışanların tanı kriterlerini karşılayıp karşılamadığına DSM-5 Tanı Ölçütleri Başvuru El Kitabı kullanılarak bakılmıştır. Bu makalede tartışılan vaka örneklerinin alanda çalışan kişilerin, danışanın ihtiyacını ona uygun ve doğru bir sekilde karșlamasını sağlayacak müdahale yöntemlerini belirlemesine katkı sağlayacağı düşünülmüştür.

Abstract

Rapid changes in structure of society varying between life styles to work conditions to overcrowding makes loneliness a common problem of urban life. Research has shown that loneliness is directly related to psychological disorders. Although loneliness in psychological disorders can be described objectively, it is very difficult for clinicians and researchers to define the nature of this experience, since the experience itself is subjective. In the light of existing literature, the qualitative characteristics and origins of the loneliness experienced in psychological disorders for the cases seen at the City Women's Counseling Center for help are discussed. Loneliness is a basic symptom in selected psychological disorders, or the person may experience loneliness as a severe problem throughout their life with disorder. Psychological disorders identified include: schizophrenia, social anxiety disorder, autism spectrum disorder, borderline personality disorder, narcissistic personality disorder, schizoid personality disorder, withdrawn personality disorder, and dependent personality disorder. Case examples presented in this article were randomly selected from the clients who applied for counseling to the City Women's Counseling Center and met the diagnostic criteria based on DSM-V. It is hoped that the case examples discussed in this article will assist counselors in determining intervention methods that will ensure that the client's needs are appropriately meet.

*Sorumlu Yazar, Ege Üniversitesi, Eğitim Fakültesi, Eğitim Bilimleri Bölümü Rehberlik ve Psikolojik Danışmanlık Anabilim Dalı, İzmir, Türkiye

e-posta:_hanife.pehlivan@ege.edu.tr

DOI: $10.31682 /$ ayna.435926

Gönderim Tarihi (Received): 30.11.2017; Kabul Tarihi (Accepted): 10.05.2018

2148-4376/ All rights reserved. 


\section{Giriş}

Yalnızlığına kaç, dostum! Seni büyük adamların gürültüsünden sersemlemiş, küçüklerin iğneleriyle de delik deşik olmuş görüyorum. Seninle nasıl susulacağını pek iyi bilir orman ve kaya. O sevdiğin ağaca benze yine sen, o geniş dallıya: sessiz ve dinlercesine sarkar o, denizin üstüne. Yalnızlığın bittiği yerde, pazar yeri başlar; pazar yerinin başladığı yerdeyse, büyük oyuncuların gürültüsü ve ağılı sineklerin vızıltısı başlar. Görüyorum ki ağılı sinekler bitirmiş seni; görüyorum ki kan akıyor deşilmiş bin bir yerinden; ve gururun kızmak dahi istemiyor. Yalnızlığına kaç! Sen küçük ve acınacak kişilere pek yakın yaşadın. Onların göze görünmez öçlerinden kaç! Onlar sana karşı öçten başka bir şey değildirler.

F. Nichezche

F. Nichezche'nin şiirinde söz ettiği yalnızlık narsistik kişilik bozukluğuna özgü kibir yüklü bir yalnızlık mıdır? Yoksa insanların eleştirilerine karşı aşırı duyarlı olan ve bu yüzden onlardan kaçan sosyal fobik bir yalnızlık mıdır? Veya derin bir umutsuzluk içeren depresif bir yalnızlık mıdır? Ya da şiirinin ortaya çıkmasına yol açan verimli bir tek başınalık mıdır? Bu soruları yanıtlamak elbette çok güçtür.

Yalnızlık üzerine, akademik ya da değil, sözü olmayan neredeyse kimse yoktur. Bazıları sanattan, bazıları felsefeden, bazıları sağduyusundan ve sözlü kültürden, bazıları kendi deneyimlerinden, bazıları psikolojiden yola çıkarak yalnızlığı anlamaya çalışmışlar; niteliklerine, nedenlerine, yararlarına, zararlarına, yapılması gerekenlere ilişkin düşünmüşler, bir çlkarımda bulunmuşlar ve bulunmaya devam etmektedirler (Karnick, 2005).

Yalnızlık, içinde bulunduğumuz yüzyılda, hızla değişen çevresel ve toplumsal koşullar nedeniyle her geçen gün daha fazla sorun haline gelmektedir. Batı ülkelerinde 190o'lerde bir evde tek başına yaşayan insan bulmak \% 1'den daha azken bir durumken 1972'de bu oran \% 6'ya 2008'de ise \% 12'ye çıkmıştır (Ernst ve Cacıoppo, 1999; Griffin, 2016).

Peplau ve Perlman (1982) genel olarak yalnızlı̆̆ı, bir kişinin arzuladığı ilişki ile yaşadığı ilişki arasındaki uyumsuzluk sonucunda oluşan, istenmeyen öznel bir psikolojik durum olarak tanımlamışlardır. Perlman ve Peplau'a (1984) göre kişiler doyum verici sosyal ilişkilerden yoksundur ya da kendisini yoksun olarak algılamaktadır. Yazarlar sosyal bilimcilerin yalnızlık üzerine yaptıkları onlarca tanımı gözden geçirmişler ve bu tanımlarda üç ortak nokta belirlemişlerdir. İlki, yalnızlık sosyal ilişkilerdeki yetersizliklerden kaynaklanmaktadır. İkincisi, yalnızlık sübjektif bir deneyimdir. Objektif bir şekilde 
gözlemlenen sosyal izolasyonla aynı şey değildir. Yani insanlar yalnızken kendilerini yalnız hissetmeyebilirler veya kalabalık içinde yalnız hissedebilirler. Üçüncüsü ise yalnızlık strese ve mutsuzluğa yol açan ve sürekliliğinde yaşamı tehdit eden bir deneyimdir (Perlman ve Peplau, 1984).

Sosyal bilimciler yalnızlığın tanımını yaparken yalnızlık ve tek başınalık olgularını birbirinden ayırmışlardır. Yalnızlık kavramı büyük oranda psikolojik ve fiziksel sağlık üzerinde olumsuz sonuçları olan insanların olabildiğince kaçındığı bir durumu tanımlarken; tek başınalık (solidute, alone) daha çok gönüllülük temeline dayanan kişinin davranışlarını gözden geçirme, düşünme, yazma, Tanrıla konuşma gibi psikolojik anlamda olgunlaşmasını sağlayan durumları tanımlamak için kullanılır (Kasari ve Sterling, 2013; McGraw, 2010).

Psikolojik ve fiziksel sağlık üzerinde olumsuz sonuçları olan yalnızlık durumu psikolojinin farklı alanlarında farklı bakış açılarıyla ele alınmaktadır. Gelişimsel perspektif yakınlık ihtiyacının doğumla birlikte başlayıp, yaşam boyu süren evrensel bir ihtiyaç olduğunu (Fromm-Reichmann, 1959), çocukluk boyunca uzun süreli yalnızlığa maruz kalmanın daha sonrasında sağlıklı yakın ilişkilerin kurulamamasına (Bowlby, 1973; Harlow, 1958), kendilik sisteminin gelişiminde aksaklıklara (Klein, 1975; Mead, 1934; Sullivan, 1953; Winnicot, 1965) ve çocukların yaşıtlarından bir şeyler öğrenememesine (Piaget, 1932) neden olduğunu ileri sürmektedir.

Sosyal psikoloji perspektifi yalnızlı̆̆ı daha çok aidiyet ihtiyacı üzerinden çalışır. Bir gruba ait olmanın insanın temel ihtiyacı olduğunu belirtir. Aidiyet ihtiyacı karşılanmadığında fiziksel sağlı̆̆ın bozulması, depresyon, kaygı gibi patolojik sorunların ortaya çıkması söz konusudur (Baumeister ve Leary, 1995; Horney, 1945; Shipley ve Veroff, 1952).

Evrimsel psikoloji perspektifi sosyal açıdan kabul görmenin ve sosyal dışlanma ve yalnız bırakılma karşısında acı çekmenin hayatta kalma ve üreme başarısına hizmet ettiğini öne sürer (MacDonald ve Leary 2005). Yapılan çalışmalar, sosyal dışlanmanın ve yalnız bırakılmanın kişide fiziksel acıya benzer bir acıya yol açtığı, bu acının kişiyi yalnız kalmamak için bir çabaya sevk ettiğini ortaya çlkarmıştır (Cacioppo ve Patrick, 2008; Eisenberger, 2012; Weeks ve Asher, 2012). Diğerleriyle bir arada olan kişilerin üreme ve hayatta kalma başarısı da daha yüksek olacaktır.

Klinik psikoloji perspektifi, daha çok yalnızlığın ruh sağlı̆̆ı üzerindeki etkisine ve kişilerin yalnızlıkla baş edebilmek ve sosyal beceri geliştirebilmek için oluşturulan müdahale yöntemlerine odaklanmıştır. Bu alanda yapılan araştırmalar uzun süren yalnızlığın yaygın anksiyete bozukluğu, obsesif kompulsif bozukluk, panik bozukluk, depresyon gibi psikolojik bozukluklar ile yeme bozuklukları, alkol kullanma, kardiovasküler hastalıklar gibi fiziksel problemlerle yüksek düzeyde ilişkili olduğunu ortaya çıkarmıştır (Griffin, 2016; Heinrich ve 
Gullone, 2006; Mushtaq, Shoib, Shah, ve Mushtaq, 2014; Shevlin, McElroy ve Murphy, 2015). Klinik psikoloji alanında yapılan çalışmalar psikolojik bozukluklarla yalnızlığın doğrudan ilişkili olduğunu ortaya koymuş.

Bilişsel psikoloji perspektifi, kişilerin yalnızlı deneyimlerinde öznel değerlendirmelerin rolüne bakmıştır (Kupersmith, Sigda, Sedikides ve Voegler, 1999; Weiss, 1973). Bu bakış açısına göre bir kişi beklediği sosyal ilişki ile deneyimlediği sosyal ilişkiyi değerlendirdiğinde, bu ikisi arasında bir uyumsuzluk görürse yalnızlı hisseder. $\mathrm{Bu}$ uyumsuzluk kişinin beklediğinden az sayıda ilişkisi varsa niceliksel, beklediğinden az miktarda duygusal destek hissediyorsa nitelikseldir. Burada kişinin yalnızlı̆̆a yol açan ilişkilerini ve eksikliklerini nasıl algıladığı önemlidir (Peplau ve Perlman, 1982). Yapılan araştırmalarda çok az sayıda çalışma farklı klinik bozukluklarda ortaya çıkan yalnızlığın niteliksel farkına değinmiştir. Gerçekte her insanın yalnızlık deneyimi biriciktir. Bu deneyimin biricikliği klinik bozukluklarda çok daha belirgindir (Heinrich ve Gullone, 2006). Diğer bir deyişle yalnızlık deneyimi her klinik bozukluk için farklı ve biricik özelliklere sahiptir.

Literatürdeki bu eksiklik Türkiye'de yalnızlık üzerine yapılmış araştırmalar için de geçerlidir. Yapılan tezler ve yazılan makaleler gözden geçirildiğinde üniversite öğrencilerinin sosyal destek ve yalnızlık düzeylerinin incelenmesi (Yılmaz ve Karaca, 2008); cinsiyetin ve bağlanma stilinin utanç, suçluluk ve yalnızlık üzerine etkisi (Akbağ ve İmamoğlu, 2010); üniversite öğrencilerinde yalnızlık: cinsiyet rolleri ve bağlanma stillerinin yalnızlı̆̆ı yordama güçleri (İlhan, 2012) ve bilişsel-davranışçı yaklaşıma dayalı grupla psikolojik danışmanın yalnızlık ve fonksiyonel olmayan tutumlar üzerine etkisi (Duy, 2003) gibi daha çok yalnızlıkla ilgili neden sonuç ilişkilerini ve müdahale yöntemlerini inceleyen araştırmalar mevcuttur. Psikolojik bozukluklarda yaşanan yalnızlığın biricikliği ve niteliği üzerine bir çalışma yoktur.

$\mathrm{Bu}$ makalede şizofreni, sosyal kaygı bozukluğu, otizm spektrum bozukluğu gibi, bulgularında yalnızlığın temel olduğu farklı psikolojik bozukluklarda yalnızlığın niteliksel farklılıkları görüşmeye gelen danışanların yalnızlığa ilişkin deneyimleri ve anlatımlarının incelenmesi üzerinden literatürdeki bilgiler ışığında ayrıştırılmaya çalışılacaktır.

\section{Yöntem}

Bu makalede sekiz psikolojik bozukluk ele alınmıştır. Bunlar şizofreni, sosyal kaygı bozukluğu (sosyal fobi), otizm spektrum bozukluğu, borderline kişilik bozukluğu, narsistik kişilik bozukluğu, şizoid kişilik bozukluğu, çekingen kişilik bozukluğu ve bağımlı kişilik bozukluğudur. Psikolojik bozukluklar içerisinden bu bozuklukların seçilme nedeni yalnızlı̆̆ın temel bir sorun olarak bu bozukluklarda çok sık ortaya çıkmasıdır. Bu nedenle de klinik literatür bu bozuklukları tanımlarken veya bozukluk belirtilerini sıralarken çeşitli ifadelerle 
yalnızlığa ilişkin bulgulara dikkat çeker (Coplan ve Bowker 2013; McGraw, 2012; Meehan, Levy, Temes ve Detrixhe, 2013). Makalede, seçilen bozukluklarla ilgili değerlendirme kapsamına alınan danışanların belirtilerinin tanılandırılma süreci DSM-5 tanı ölçütleri başvuru kitabı kullanılarak yapılmıştır. Tanı kriterlerini karşılayan danışanlar, değerlendirme yapılan bozukluk kapsamında vaka örneği olarak sunulmuştur.

Araştırmada sunulan vaka örnekleri Belediye’ye bağlı kadın danışma merkezine başvuran danışanlar arasından seçilmiştir. Araştırmacının kendisi kadın danışma merkezinde klinik psikolog ve kurum sorumlusu olarak çalışmıştır. Danışanlar, yaşadıkları bozuklukların bulgularının makalede vaka sunumu olarak kullanılacağı konusunda bilgilendirilmiş ve sunum için danışanların izni alınmıştır. Danışanlar kimlik bilgilerinin gizli kalması ve sadece bulgularının kullanılması koşulu ile araştırmacıya izin vermişlerdir. $\mathrm{Bu}$ nedenle vakaların kimlik bilgileri tamamen gizlenmiş, makalede kod harfi kullanılmıştır.

\section{Vaka Sunumları}

\section{Şizofreni ve Yalnızlık}

Şizofreni klinik bozukluklar yelpazesinde önemli bir yer tutar. Sanrlar (aksi kanıtlandığı halde kişinin inanmaya devam ettiği inançlar); halüsinasyonlar (dışsal bir uyaran olmadığı halde kişinin bir uyaran algılaması ve buna inanması); düşüncelerin raydan çıkması ya da çağrışımlarda gevşeklik gibi dezorganize düşünme şekli; katatonik bozukluk gibi anormal motor davranışlar, konuşmada fakirlik, enerji ve haz kaybı, asosyallik gibi negatif belirtiler şizofreninin temel bulguları içerisinde yer alır (DSM-5, 2013; Davison ve Neale, 1997).

“A, 21 yaşında, üniversite öğrencisi ancak okula devam edememekteydi. Görüşmeye annesiyle geldi. Anne, oğlunun son bir yıldır insanlarla ilişki kurmadığını, son altı aydır da evden çıkmadığını, evde de sürekli olarak odasında kaldığını, odasından sadece yemek yemek ve tuvalete gitmek için çıktığını, gününün büyük kısmını yatakta büzülmüş bir şekilde yatarak ya da kendi kendisine konuşarak geçirdiğini belirtti. Görüşmede A'nın öz bakımının yetersiz, yüz ifadesinin oldukça künt ve iletişim kurmakta isteksiz olduğu gözlendi. Görüşme esnasında A, görüşmeye gelmek istemediğini çünkü onu odasında her gün ziyaret eden fötr şapkalı, uzun siyah paltolu adamın "sakın evden çıkma, sadece benimle konuş eğer başkalarıyla konuşursan gece sana tecavüz ederim” dediğini, bu yüzden korktuğunu ve konuşmak istemediğini, zaten eskiden beri insanlarla birlikte vakit geçirmekten, onlarla sohbet etmekten hiçbir şekilde zevk almadığını, bu nedenle onlardan uzak durmak istediğini söyledi. Daha fazla konuşamayacağını, çünkü fötr şapkalı adamın ayak seslerini duyduğunu söyleyerek sustu ve bir daha görüşme boyunca konuşmadı. Gerçekte böyle birisi yoktu. Annesi A'nın çocukluğundan beri hep içine kapanık olduğunu, genellikle tek başına oynamayı tercih ettiğini söyledi. A'nın babaannesinde de benzer bir problem 
vardı ve babaannesi, A, kardeşi annesi ve babasıyla birlikte yaşamaktaydı. A'nın annesi evlendiğinden bu yana kayınvalidesi yüzünden eşiyle şiddetli kavgalar etmekteydi ve A bu kavgaları görerek büyümüştü."

Bu vakada A'nın yaşadığı insanlarla iletişim kurma isteğindeki yokluk A'nın derin bir yalnızlık yaşamasına sebep olmaktadır ve bu yalnızlık A'nın yaşamında çeşitli sorunlara yol açacak gibi görünmektedir. A’nın yaşadığı yalnızlığın niteliğine bakıldığında, Peplau ve Perlman’ın (1982) tarif ettiği talep edilen ilişki ile deneyimlenen ilişki arasındaki uyumsuzluktan farklı bir durum söz konusudur. Burada A’nın arzuladığı bir ilişki yoktur. Dolayısıyla yaşadığı durumun istenmeyen bir yanı da yoktur. Buradaki yalnızlık daha çok tek başına kalma isteği gibi görünmektedir. Ama A’nın tek başına kalması üretkenlik içeren bir süreç değildir. Tam tersine uzun vadede A'nın yaşamında çok ciddi olumsuz sonuçları olacak bir tek başınalık durumudur. A’nın yaşadığı yalnızlık ya da asosyallik, sosyal anhedoni olarak adlandırılan bir durumun sonucunda ortaya çıkmaktadır. Sosyal anhedoni kişinin sosyal ilişkiler kurarken çekinmesi, kaygı duyması ya da sosyal ilişkilerden korkması değildir. Sosyal ilişkilere ilgi duymaması, sosyal ilişki kurmaktan hoşlanmaması ve kurduğunda pozitif bir duygulanım hissetmemesidir. Diğer insanlara hiçbir şekilde ilgi duymama daha çok kişilik özelliğiyle ilişkilidir ve nihayetinde kişinin hayatında süreğen bir yalnızlıkla (Kwapil, Silvia ve Barrantes-Vidal, 2013), bazen de başkalarının bakımına muhtaçlıkla sonuçlanır. Bu yalnızlık depresyonda, sosyal fobide, otizimde veya bir kişilik özelliği olan içedönüklükte yaşanan yalnızlıktan farklıdır. Silvia ve Kwapil (2011), sosyal anhedoni yaşayanların, sosyal ilişkilerin insanlarda ortaya çıkardığı ödüllendirici mekanizmadan yoksun olduklarını ifade etmişlerdir. Benzer şekilde Baumeister ve Leary (1995) çalışmalarında şizofrenlerin insanın doğasında bulunan ait olma ihtiyacını hissetmediklerini ve bu durumun kronik bir nitelik taşıdığını ortaya koymuşlardır. Nedenine ilişkinde kişinin beynin nörofizyolojik süreçlerindeki bozulmalara veya kişinin erken çocukluk döneminde yaşanan bağlanma süreçlerindeki aksaklıklara vurgu yapmışlardır. Nitekim yukarıdaki vakada A'nın yaşadığı tamda tariflenen biçimde bir yalnızlıktır. İnsanlara karşı yoğun bir ilgisizlik yani sosyal anhedoni, şizofrenideki yalnızlığın başlangıcı ve yıkım nedenlerinden biridir.

Yalnızlı̆̆ın ciddi bir problem olduğu bir diğer bozukluk sosyal kaygı bozukluğudur. Aşağıda B vakası üzerinden sosyal kaygı bozukluğunda yaşanan yalnızlı̆̆ın niteliği ve nedenleri tartışılacaktır.

\section{Sosyal Kaygı Bozukluğu ve Yalnızlık}

Sosyal kaygı bozukluğu bir kişinin sosyal ortamlarda yaşadığı başkalarının varlığı ve onu gözetlemesi olasılığıyla ilgili olarak mantıklı olmayan, ısrarlı bir kaygı ve korku 
yaşamasıdır. Sosyal kaygısı olan kişilerin, birlikte olduğu insanların onu olumsuz değerlendireceğine ilişkin güçlü inançları vardır ve bu tip ortamlardan olabildiğince kaçınırlar veya maruz kaldıklarında yoğun bir şekilde utanırlar. Yaşadıkları utanç insanların arasına bir şekilde katıldıklarında onları duygu ve düşüncelerini ifade etmekten alıkoyar. Bu korku ve kaygı sahneye çıkma vb. spesifik bir durumda ortaya çıkabileceği gibi, grupla yemek yeme, ortak tuvaletleri kullanma, insanların içinde kendini ifade etme gibi sosyal etkileşim gerektiren yaşam alanlarında da yaşanıyor olabilir (DSM-5, 2013; Davison ve Neale, 1997). Sosyal kaygısı olan kişiler sosyal anhedoni yaşayan kişilerden farklı olarak insanlarla birlikte olmak isteler ancak değerlendirilme kaygısı yüzünden diğerleriyle birlikte olmakta güçlük çektikleri için onlardan uzak dururlar veya kurdukları ilişkilerde kendileri olamazlar ve bu ilişkiden doyum alamazlar. Dolayısıyla çok derin bir yalnızlık hissederler (Brown, Silvia, Myin-Germeys ve Kwapil, 2007).Gelişimin her aşamasında ciddi güçlüklere yol açan sosyal kaygı, süreğenleştiğinde depresyon, alkol ve madde kullanımı gibi başka klinik bozuklukları kolaylıkla tetikleyebilir.

“B, 55 yaşında, emekli memur. İlk görüşmeye oğluyla birlikte geldi. Görüşmeye kendi isteğiyle gelip gelmediği sorulduğunda 'aslında yıllardır kafasının bir köşesinde böyle bir yardım almak istediğini ancak bunu ifade etmeye çekindiği için bir türlü yardım alamadığını, şimdide oğlunun itelemesiyle gelebildiğini' söyledi. Geliş nedeni sorulduğunda ise, çok yalnız olduğunu, evden çok zor çıtığını, sürekli başka insanların onun hakkında neler söyleyebileceklerine ilişkin kuruntularla meşgul olduğunu, çocukluğundan beri hep çekingenlik yaşadığını ve bunu kimseye söyleyemediğini belirtti. İnsanların arasında nasıl davranacağını bilemediği için başka insanlar için çok basit görünen şeyleri bile yapmakta güçlük çektiğini ve bunları yapmak zorunda kalırsa aşırı utandığını anlattı. Örneğin, evinin yakınında bir kahvehaneye gittiğinde, erkeklerin arasında çok çok az konuşmakta, çay içerken elleri titremekte ve bu yüzden çay içememekteydi. Kahveden kalkıp eve dönmesi gerektiğinde, insanlara 'ben gidiyorum, hoşça kalın' demenin zorluğu yüzünden hep oturduğu masadan en son o kalkmaktaydı. Bir dolmuşa binmek zorunda kalsa 'müsait bir yerde inecek var' diyemediği için inmesi gereken durağa yaklaştığında durakta inecek başka birisi olursa onun arkasından inmekteydi. Ĕger onun ineceği durakta inen biri yoksa durağı kaçırmaktaydı. Aslında B'de diğer insanlar gibi olmak istediğini, gezmeyi, insanlarla birlikte olmayı sevdiğini, yüksek sesle şarkılar söylemek ve kendisini olduğu gibi dışa vurmak istediğini belirtti. Ancak bunları yapamadığı için yalnızlığa mahkûm kalmaktaydı ve yalnızlıktan bıkmıştı.”

Bu vakada B’nin yaşadığı yalnızlığın niteliğine bakıldığında, Peplau ve Perlman’ın belirttiği gibi (1982) bir kişinin beklentileriyle deneyimleri arasındaki uyumsuzluğa çok uygun bir yalnızlıktır. B, Weiss’in (1973) kavramsallaştırdığı gibi hem duygusal olarak kendisini yalnız hissetmektedir hem de sosyal olarak etrafındaki insan sayısı çok azdır ve bu yüzden yalnızdır. Sosyal kabul arzusu insanın hayatta kalmasını sağlayan, evrimsel süreçte ortaya çıkmış önemli mekanizmalardan birisidir (DeWall ve Bushman, 2011). B'de ilk vaka 
olan A'dan farklı olarak bu arzuya uygun davranmakta yani insanlarla birlikte olmak istemekte ve yapabildiğinde bu birliktelikten hoşnut olmaktadır. Ancak B'nin yaşadığı utangaçlık ve beceri eksikliği daha sonra otizmde bahsedilecek olan beceri eksikliğinden farklıdır. B insanların beden ifadelerini, sözsüz işaretlerini ve iletişimdeki çift mesajları kolay bir şekilde ayırt edebilmektedir. Fakat değerlendirilme kaygısı yüzünden insanlarla birlikte olduğunda yaşadığı sıkıntı, onlarla birlikte olma isteğinden daha baskın çıkmakta B'yi yalnızlığa mecbur bırakmaktadır. İnsanlarla birlikte olduğunda da kendisi gibi davranamadığı için derin bir yalnızlık duygusu yaşamaktadır. Sosyal kaygı bozukluğundaki yalnızlık temelde B’nin yaşadığı gibi kişilerin sosyal işaretleri okuyamamasından veya ilişki kurmadaki talepsizliğinden değil sosyal beceri eksikliğinden kaynaklanmaktadır. Sosyal işaretleri okuyamamak C vakasında anlatılacak olan otizm spektrum bozukluğunun bir özelliğidir.

\section{Otizm Spektrum Bozukluğu ve Yalnızlık}

Otizm spektrum bozukluğu (OSB) erken çocukluk döneminde başlayan; sosyal etkileşimde ve iletişimde ciddi eksikliklere ve sorunlara yol açan; sınırlı ve tekrarlayan ilgi, davranış ve aktivite örüntüleri olan ve ömür boyu süren bir rahatsızlıktır. Sosyal etkileşimdeki problemler bozukluğun temel özelliğidir ve gündelik yaşamı idame ettirmede önemli problemlere neden olur (DSM-5, 2013; Kasari ve Sterling, 2013). OSB olan kişilerin genellikle yalnız kalmayı ya da insanlarla minimal düzeyde ilişki kurmayı tercih ettiği ve bozukluğun organik kökenli olduğu kabul edilir (White ve Roberson-Nay, 2009). Bazı OSB olan kişiler sahip oldukları sosyal beceri yoksunluğunun hiçbir şekilde farkında değilken, çoğu yaşadıkları sosyal beceri eksikliğinin keskin bir şekilde farkındadırlar (Attwood 2000). Otistik kişilerin çoğu akranlarından çok daha fazla yalnızlık yaşadıklarını ve akranlarıyla daha fazla ilişki kurmak istediklerini ifade etmektedirler (Bauminger ve Kasari 2000). Ancak göz teması kuramamak, yüz ve beden ifadesini okuyamamak, iletişim kurarken karşılıklılığı sağlayamamak gibi nedenlerle ilişki kuramazlar (Kasari ve Sterling, 2013) ve yalnızlı̆̆a mecbur kalırlar.

“C, 24 yaşında, kadın, matematik bölümünde öğrenci. 3 yaşında konuşmasında gecikme, göz teması kuramama, söylenenleri duymuyormuş gibi davranma, dalıp gitme, yiyecek konusunda aşırı seçici davranma, yüksek sese maruz kaldığında çı̆̆lık atma, dönen nesnelere karşı yoğun ilgi duyma, kendi eksenin etrafında aşırı derecede dönme şikâyetleriyle ailesi çocuk ve ergen psikiyatrisi polikliniğine başvurmuş. Yapılan değerlendirmeler sonucunda C'ye otizm spektrum bozukluğu tanısı konulmuştur ve özel eğitime yönlendirilmiştir. C, 3 ile 10 yaş aralığında haftada bir veya iki gün, bir saat özel eğitim hizmeti almıştır. C, 6 yaşına geldiğinde konuşmayı sökmüş, 7 yaşında yaşıtlarıyla birlikte ilköğretime başlamıştır. Yüksek fonksiyonlu bir otistik olduğu için akademik açıdan herhangi bir zorluk yaşamamıştır. Özellikle 
sayısal alanda oldukça başarılıdır. 10 yaşına geldiğinde belirtileri bir miktar azaldığı için ailesi özel eğitimi bırakmıştır. C, psikolojik yardım almak için başvurduğunda temel başvurma nedeninin yalnızlık olduğunu söyledi. İnsanlarla ilişki kurmayı istemekteydi. Ancak bunu nasıl yapacağını bilememekteydi. C'nin başkalarının onun hakkında ne düşüneceğine ilişkin bir kaygısı yoktu. Hatta buna dair bir fikri bile yoktu. Yani insanların niyetlerini sezememekteydi. İletişime nasıl başlayacağını ve nasıl sürdüreceğini bilememekte ve insanları bir türlü anlayamamaktaydı. Ona insan ilişkileri aşırı karmaşık gelmekteydi. İlişki kurmak için sosyal medyayı kullanmaktaydı. Fakat burada da ciddi sorunlarla karşılaşmaktaydı. C sosyal medya üzerinden tanıştığı bazı kişilerin istismarına maruz kalmıştı. Sanal ortamda yaşadığı olaylara herhangi bir anlam verememiş, görüşme esnasında bu durumu sadece 'biraz garip bir olay' olarak nitelendirmişti. Daha sonrasında sanal ortamda tanıştığı kişiler C'yi tehdit etmişti."

Burada C, otizmde çok temel bir sorun olan, yoğun bir şekilde iletişim kurma güçlügüu yaşamaktadır. C, sosyal medya ortamında ilk kez karşılaştığı yetişkin bir erkeğin çok mahrem bir konuyu sıradan bir şeymiş gibi paylaşması durumunu şüpheyle karşılamamış bu davranışın arkasında bir art niyet aramamıştır. Bunun nedeni C'nin iletişim kurarken verilen çift mesajları anlayamamasıdır. C, Bauminger ve Kasari’nin (2000) çalışmalarında ifade ettiği gibi ciddi bir yalnızlık yaşayan ve akranlarıyla hem duygusal hem de fiziksel ihtiyaçlarını karşılamak için ilişki kurmak isteyen otistikler grubundandır. Ancak C., Kasari ve Sterling’in (2013) çalışmalarında belirttiği otistik kişilerin temel ortak özelliklerini taşımaktadır. C kalıtımsal olarak insanların sözlü ve sözsüz mesajlarını okumakta güçlük çekmekte, insanların art niyetli olabileceğini fark edememektedir. Bu yüzdende ya zarar görerek yalnız kalmakta ya da doğrudan yalnız kalmaktadır. C’nin yaşadığı yalnızlık A'nın ve B'nin yaşadı̆̆ yalnızlıktan farklıdır. A, sosyal anhedoni sonucunda uzun vadede zarar verici bir yalnızlığı bizzat tercih etmektedir. B, yalnız kalmayı istememekte, iletişimdeki sözlü ve sözsüz işaretleri okuyabilmektedir. Ancak yoğun değerlendirilme kaygısı onu yalnız bırakmaktadır. C'nin değerlendirilme kaygısı yoktur. Hayır demesi gerektiğinde kolaylıkla "hayır" diyebilir. Ancak iletişimi başlatma, sürdürme, sosyal etkileşimdeki işaretleri okumadaki yetersizliği yüzünden yalnız kalmaktadır. C, Attwood’un (200o) söz ettiği gibi, otistiklerin bir kısmı için geçerli olan, yaşadı̆̆ı sosyal beceri eksikliğinin keskin bir şekilde farkındadır. Ancak bunu nasıl telafi edeceğini bilemediği için arzuladığı ilişki ile yaşadığı ilişki arasında ciddi bir uyumsuzluk yaşamakta hem duygusal olarak hem de sosyal olarak yalnız kalmaktadır.

\section{Kişilik Bozuklukları ve Yalnızlık}

Bir kişi çeşitli nedenlerden dolayı yalnız kaldığında bu yalnızlık deneyimini pozitif yani onu geliştiren bir şekilde mi yaşayacağı yoksa bu süreçten zarar mı göreceği gelişim 
süreci boyunca şekillenen kişiliğinin özelleşmiş boyutlarına bağlıdır. Özellikle kişinin iç kaynaklarının niteliği, yalnızlığı kendini zenginleştiren bir deneyim olarak yaşamasında oldukça etkilidir (Meehan, Levy, Temes ve Detrixhe 2013; Winnicot, 1965).

Kişilik, bir kişinin gündelik yaşam içinde çeşitli ortamlarda ortaya çıkan, tutarlı ve süreğen bir niteliğe sahip olan duygu, düşünce ve davranış örüntülerine denir. Kişilik mizacın, içselleştirilmiş deneyimlerin, insanın kendisi ve dış dünyası hakkındaki şemalarının, yaşamdaki deneyimlerle zaman içinde şekillenen davranış örüntülerinin kompleks bir etkileşimidir ve psikolojik açıdan işlevsel olmanın temel dinamiğini oluşturmaktadır. (Meehan ve ark. 2013). Kişiliğimizi nasıl yaşayacağımızda çocuklukta bakım verenle ve dış dünyayla kurduğumuz ilişkiden edindiğimiz içsel temsillerimizin merkezi bir rolü vardır (Blatt, Auerbach ve Levy, 1997; Kernberg, 1975). Kişiliğimizin niteliğini ve yapılanma biçimini oluşturan bu içsel temsiller başarı, yeniden başlama ve esnek olma kapasitemizi doğrudan belirler.

Kişilik bozuklukları kişinin içinde yaşadığı kültürün beklentilerinden sapan, sosyal ve iş yaşamındaki işlevselliğini bozan, çok eskiden beri var olan, yayılgan, esnemeyen davranış örüntüleri ve içsel yaşantılardır. Bu yaşantıların bazıları psikolojik bozukluklara neden olabilirler (DSM-5, 2013; Davison ve Neale, 1997).

Kişilik bozuklukları üzerine yapılan kuramsal açıklamaların pek çoğu, kişilik bozukluklarını açıklarken kişinin kimlik duygusunda ve kişiler arası ilişkilerinde ortaya çıkan bozulmalara ciddi bir yer verir. Bu bozulmalar temelde kişiler arası ilişkilerde problemlere, yalnız kalmaya veya derin bir yalnızlık hissinin yaşanmasına yol açmaktadır (Meehan ve ark. 2013). Örneğin, kişiler arası ilişkilerde fakirleşme, bu ilişkilerden hiçbir şekilde zevk almama (anhedoni) ve yoğun bir şekilde yalnız kalma isteği (asosyallik) şizoid kişilik bozukluğunun içinde yer aldığı A kümesi kişilik bozukluklarında; derin bir boşluk, yalnızlık duygusu ve terkedilme korkusu borderline kişilik bozukluğunun içinde yer aldığı B kümesi kişilik bozukluklarında; başkalarına olan bağımlılığı yüzünden aşırı boyun eğici davranan ve kendisi olmaktan vazgeçen, bu nedenle de kendisini çok yalnız hisseden, bağımlı kişilik bozukluğunun içinde yer aldığı C kümesi kişilik bozukluklarında yaşanan yalnızlı̆̆a ilişkin belirtilerden bazılarıdır (Kring, Johnson, Davison, ve Neale, 2014)

Kişilik bozukluklarında ortaya çıkan söz konusu yalnızlığın kaynağını anlayabilmek için psikodinamik teorilere bakmak yararlı olacaktır. Özellikle Winnicot’un (1965), “tek başına/yalnız olma kapasitesi” kavramı aydınlatıcıdır (Long ve Averill, 2003). Winnicot'a göre yalnızlıkla baş etme kapasitesi kendiliğin erken çocukluk döneminde diğerleriyle kurduğu güvenilir ve stabil bir ilişkiyi ve bu ilişkiyi sağlayan kişileri içselleştirmesi sonucunda şekillenir. Winnicot'un bu söylemi daha sonra bağlanma kuramına ve nesne ilişkileri kuramına temel oluşturmuştur. Bu kuramlara göre, diğerleriyle ilişki içindeki kendiliğin bir 
temsili olan normal kişilik gelişimi, kişilik öğelerinin ayrışması ve bütünleşmesi sürecinde oluşur (Blatt, Auerbach ve Levy, 1997; Kernberg, 1975). Bebeklerin yaşamın başlangıcındaki acıya ve hazza ilişkin belirli bir düzenlilik içeren deneyimleri büyüme sürecinde kendiliğin ve diğerlerinin ayrışmış ve bütünleşmiş temsillerine dönüşür. $\mathrm{Bu}$ dönemde, bebek ihtiyaç duyduğunda bakım verenin uygun bir şekilde devreye girmesi sadece bebeklerin o anki ihtiyaçlarını gidermeye ve duygularını düzenlemeye yaramaz. Aynı zamanda bebeğin zihninde bakım veren olmadığında bakım vereni hatırlamasını sağlar ve bu durum bebekliğin 16-18. ayına denk gelir. Buna "hatırlamada süreklilik" adı verilir. Hatırlamada sürekliliğin kazanılması 2.5-3 yaş arasında gerçekleşen “nesne sürekliliği” ne temel oluşturur ve kişilerin yaşamın sonraki evrelerinde yalnız kaldığında onu seven ve ona bakım veren kişileri içsel bir şekilde canlandırmasını sağlar. Böylelikle yalnız kaldıklarında yalnızlık onlar için tehlikeli olmaktan çıkar ve geliştirici bir deneyime dönüşür (Meehan ve ark. 2013). Eğer "hatırlamada süreklilik”te bir sorun varsa, bu sorun dişavurumu kişilik bozuklukları şeklinde ortaya çıkan güçlü bir yalnızlık duygusuna sebep olur. Aşağıda bozukluk sürecinde yalnızlığın temel bir problem olarak ortaya çıktığı kişilik bozuklukları ve ortaya çıkan bu yalnızlığın niteliksel farkları tartışılmıştır.

\section{Borderline Kişilik Bozukluğu ve Yalnızlık}

"D, 28 yaşında, kadın; kasiyerlik, satış elemanlığı gibi pek çok geçici işte çalışmış. 1.5 yaşındayken annesini kaybetmiş. Babası ve erkek kardeşleriyle büyümüş. Babası kendisinin ve kardeşlerinin davranış sorunlarıla baş edebilmek için sık sık şiddete başvurmuş. D, 7 yaşındayken 18 yaşındaki komşusunun oğlunun tecavüzüne maruz kalmış. Bu tecavüz D, 13 yaşına gelinceye kadar zaman zaman tekrarlamış. D, görüşmede çok mutsuz olduğunu; içinde çok derin bir boşluk ve yalnızhk hissettiğini; bu hissi hiçbir şekilde gideremediğini; zaman zaman bileklerini keserek, aşurı alkol tüketerek, D’nin deyimiyle 'saçma sapan insanlarla' cinsel birliktelik yaşayarak kendine zarar verdiğini; insanlar ilk tanıdığında aşırı sevdiğini ancak kusa sürede onlardan nefret ettiğini hatta tiksindiğini söyledi. Bu durum kendisi içinde geçerliydi. Aşır tutarsızd ve kim olduğunu tanımlamakta güçlük çekmekteydi. Bildiği tek şey dengesizliği ve derin yalnızlı̆̆ıydı. Yalnızlık C’yi çok keskin bir biçimde yakaladığında 'içinde korkunç bir ölme isteği belirdiğini’ söyledi. $B u$ duygularından dolayı insansız yapamamaktaydı. Duyguların çok yoğun ve uçlarda yaşamakta, hiçbir şeye tutunamamaktaydr.”

D tipik bir borderline kişilik bozukluğudur (BKB). BKB olan kişiler D'nin deneyimlediği gibi kişiler arası ilişkilerde, kendilik imgesinde, duygu durumunda sabit kalamazlar ve bariz biçimde dürtüsel davranırlar (DSM-5; Kring ve ark., 2014). Diğer insanlara yönelik tutumları ve duyguları kısa bir süre sonra dikkat çekici derecede ve açıklanamaz biçimde değişebilir. Duygularının değişkenliği tutkulu bir idealleştirmeden, hor 
gören bir öfkeye doğru, bir uçtan öbür uca savrulmak şeklinde keskin ve hızlı olur. Kumar oynama, para harcama, cinsel ilişki, yemek ziyafetleri gibi önceden kestirilemeyen kendisine zarar verecek düzeyde dürtüsel davranışları vardır. Genellikle fırtınalı ve gelip geçici ilişkiler kurarlar. Yalnız kalamazlar ve sürekli olarak terk edilmekten korkarlar. Kronik depresyon ve derin boşluk duyguları yüzünden intihar riski barındırırlar ve çok büyük bir kısmının erken yaş travma öyküsü vardır (Kring ve ark., 2014). Gunderson (1996) BKB'nin diğer bozukluklardan ayıran temel özelliğin yalnızlığa karşı hissedilen tolerans yokluğu olduğunu, bozukluğun kendine zarar vermek, öfke patlamaları, duygusal dengesizlik gibi diğer bulgularının ana sebebinin bu toleranssızlıktan ve terkedilme korkusundan kaynaklandığını iddia eder. Benzer şekilde Klonsky (2008) kronik boşluk duygusuyla izolasyon duygusunun güçlü bir şekilde birbirleriyle ilişkili olduğunu ve yalnızlığın kişilerin kendine zarar vermesine ciddi bir zemin oluşturduğunu ortaya çıarmıştır. $\mathrm{Bu}$ derin yalnızlık duygusunun çekirdeğinde kişinin erken çocukluk döneminde bakım verenle/diğerleriyle kurduğu problemli ve dengesiz bir ilişkinin içselleştirilmesi yatar (Meehan ve ark.). Bu ilişki temsili, "hatırlamada süreklilik" te ciddi sorunlara yol açar. BKB hastası kişi yalnız kaldığında zihni de yapayalnızdır ve bu boşluk katlanılmazdır. Aslında BKB’deki yalnızlık kişinin zihninde diğerlerinin temsiline dair imgesel düzeyde bir yokluk yaşamasından kaynaklanır ve bozukluktaki diğer semptomlar diğerlerinin imgesinin yokluğuyla ve bu yokluğun yarattığı acıyla başlar. Tıpkı D'de olduğu gibi. D'de B'de ve C'de farklı şekillerde ortaya çıkan bir beceri eksikliği yoktur. D insanlarla ilişki kurabilmektedir. Ancak etrafında insanların olması D’nin yalnızlık hissini gidermeye fayda etmemektedir. Çünkü D’nin zihninde imgesel düzeyde kimse yoktur ve bu yokluk derin bir yalnızlık duygusuna ve bu duygu da D’nin kalabalık içinde de yalnız hissetmesine neden olur. D’nin yaşadığı durum bir miktar bir sonraki bozuklukta anlatılan narsistik kişilik bozukluğu içinde geçerlidir.

\section{Narsistik Kişilik Bozukluğu}

"E, 40 yaşında, erkek, bir firmada inşaat mühendisi olarak çalışmaktadır. Çahş̧ı̆̆ firmada oldukça aktif, başarll, kısa sürede nitelikli bir şekilde iyi işler çıkaran, yakışıkl ve bu konuda çok sık geri bildirimler alan ve sürekli bu bildirimleri almak isteyen biridir. Isşteki başarısıyla ve fiziksel özellikleriyle etrafindaki insanların ilgisini çekmektedir. Ancak $E$ işyerinde diğer insanlarla kurduğu ilişkide çok sık öfke nöbeti yaşamakta, ekip çalışması gerektiren işlerde sorun çıkarmaktadır. Bu nedenle müdürü E'nin terfiini durdurmuş, E'ye bir psikolojik yardım alması gerektiğini, eğer bu şekilde giderse iş başarısına bakmayacağın ve sözleşmesini yenilemeyeceğini söylemiştir. Bunun üzerine $E$ danışmaya başvurmuştur. Görüşmede aslında hiçbir yardıma ihtiyacı olmadığını, kendisinin mükemmel biri olduğunu, suradan insanlarn onun mükemmelliğini görmekten yoksun olduğunu, kendisini çok yalnız hissettiğini ve bu yüzden mutsuz olduğunu ancak yalnızh̆̆ın 
başarnl ve mükemmel insanlarm kaderi olduğunu söyledi. E görüşmede, büyürken anne babasını en iyi olması gerektiği yönünde çok baskısı olduğunu, sınavlarda 90 almasının bile evde başarısızlık olarak değerlendirildiğini belirtti."

Narsistik kişilik bozukluğuna sahip kişiler (NKB) E'de olduğu gibi kendi benzersizliklerini ve yetilerini büyüklenmeci (grandiyöz) bir gözle görürler ve empati yokluğu bozukluğun temel özelliklerindendir. Kibir, çekememezlik, empati yokluğu, birtakım haklara ve avantajlara sahip olma duyguları yüzünden kişiler arası ilişkileri bozuktur (DSM-5; Kring ve ark., 2014) ve yoğun bir şekilde yalnızlık hissederler. NKB olanlar yalnızlıkla kurduğu ilişki oldukça karmaşıktır. Başkalarının hayranlığını kazanmak gibi büyüklenmeci ihtiyaçları yüzünden diğerlerine muhtaçtırlar ancak yakınlık ihtiyaçlarını da inkâr ederler. E'de benzer bir şeyi yaşamaktadır. E mükemmeldir ve diğerlerine ihtiyacı yoktur ama mükemmel olduğunu bilmek için diğerlerine ihtiyacı vardır. Kernberg'e $(1975,1984)$ ve Kohut'a (1971) göre NKB çocukların, erken çocukluk döneminde anne babanın aşağılayıcı, reddedici ve duygusal açıdan yoksun bırakıcı tutumlarına maruz kalmalarının sonucunda gelişir. $\mathrm{Bu}$ çocuklar kendi büyüklenmeci ihtiyaçları dışında bir şeyle ilgilenmeyen tutarsız ebeveynlerle baş etmek zorundadır. Çocuğun kendisini sevilen ve becerikli birisi olarak hayal ettiği idealize kendiliği dış dünyanın sevgisizliği ve yıkıcılığı karşısında bir sığınaktır. Onaylanmamış kendilik temsili ile büyüklenmeci kendilik temsili entegre olmamıştır. İki kendilik arasındaki zıtlık ve bağlantısızlık diğer insanların hayranlığına duyulan açlık, boşluk duygusu ve utanç ile dışa vurur kendini. Ve bu duygular o denli esir alır ki kişiyi, diğerlerinin dünyasına ilgi duyamaz hale gelir ve empati duygusu geliştiremez. Bu vakada E’nin yalnızlığı D’ninkinden farklıdır. D’nin zihninde imgesel düzeyde bir boşluk vardır. Oysa E’nin kendisini çok sevilen ve becerikli, mükemmel birisi olarak hayal ettiği idealize kendiliğine ve kendi büyüklenmeci ihtiyaçlarıyla meşgul bir bakım verenin/ebeveynin sebep olduğu hiçbir şekilde onaylanmamış kendiliğine ilişkin bir temsil vardır. Birbirine tamamen zit ve bütünleşmemiş bir şekilde var olan kendilik temsilleri, E'de olduğu gibi, bir paradoksa ve bu paradoksta yalnızlığa yol açar.

Erken çocukluk travmaları borderline ve narsistik kişilik bozukluklarında olduğu gibi F vakası üzerinden anlatılacak olan şizoid kişilik bozukluğundaki yalnızlığın ortaya çımmasında da etkilidir.

\section{Şizoid Kişilik Bozukluğu}

"F, 45 yaşında, erkek, bir firmada bilgisayar programcısı olarak çalışmaktadır. Annesinin baskısıyla, annesiyle birlikte görüşmeye gelmiş. Görüşme boyunca $F$ kısacık cümlelerle, çok az konuştu. F kendinde hiçbir şekilde bir sorun görmemektedir. Sadece insanlara karşı bir ilgisi yoktur ve insanlarm bunu neden bir sorun olarak gördüğünü anlamamaktadır. Yaşamın bu şekilde sürdürmeyi 
istemektedir. Konuşurken yüz ifadesinde bir küntlük vardır. $F$ Annesiyle yaşamaktadır. Annesi $F$ bebekken kocasindan yoğun fiziksel ve cinsel şiddet görmüş̧ü ve doğru düzgün F ile ilgilenememişti. Bebekliğinde sık sık F'de babasının şiddetine maruz kalmışt. Annesi çocukluğundan beri F’nin çok sessiz olduğunu, diğer çocuklarla birlikte oynamayı sevmediğini, ergenliğe girdiğinde kızlara karşı bir ilgi duymadığını her zaman biraz tuhaf olduğunu söyledi. Anne çok yaşlandığımı, kendisini ölüme yakın hissettiğini, ölmeden önce gözünün arkada kalmaması için oğlunu evlendirmek istediğini ancak oğlunun buna yanaşmadığını belirtti. Ölürse oğlu yalnız kalacağı ve hayatını sürdürmede çok güçlük çekeceği için endişelenmekteydi. Çünkü Fnin insanlarla ilişki kurması gereken işlerini annesi halletmekteydi."

Şizoid kişilik bozukluğu (ŞKB) olanlar, F’nin yaşadığı gibi, diğer insanlarla ilişki kurmak istemezler ve güçlü duygular hissetmekten büyük oranda yoksundurlar (DSM-5; Kring ve ark., 2014). Övülmeye, eleştirilmeye ve başkalarının duygularına karşı ilgisizdirler. $\mathrm{Bu}$ bulgular şizofreninin negatif bulgularına benzerdir. Empati yokluğu ise narsistik ve antisosyal kişilik bozukluğunda da görülür. Millon ve Davis (1996), ŞKB olan kişilerde yaşamın ve insan ilişkilerinin haz ve mutluluk veren taraflarını, insanların ihtiyaçlarını ve duygularını hissedememekle ilgili doğumla birlikte gelen bir yetersizlik olduğunu iddia etmişlerdir. Bu yetersizlikle dünyaya gelmek yalnızlığı da beraberinde getirir. Öte yandan özellikle psikanalitik kuramcılar (Fairbairn, 1952; Mahler, Pine ve Bergman, 1975; Winnicot, 1965) erken dönemde anne/bakım verenin kaybının ya da reddedici, duygulardan yoksun bırakıcı anne/bakım verenin tutumunun şizoid gelişimin çekirdeğini oluşturduğunu söylerler. Özellikle güvenlik ihtiyacının ve diğerleriyle ilişki kurmanın birincil kaynağı olan bakım verenle/anneyle ayrılma bireyleşme döneminde yakınlık, etkileşim ve bağlanma ihtiyacını sağlıklı bir şekilde çözemeyen çocuk dış dünyayı tehdit dolu ve baş edilmez bir şey olarak içselleştirecektir. Ve bu tehditten uzaklaşmak için kendi içine çekilip yalnızlığa gömülecektir. (Martens, 2010). Böyle bir durumda yalnızlık travmatik yaşantılara maruz kalmakta olan bebeğin dış dünyanın tehditlerinden korunmak için yaratmış olduğu koruyucu bir kapsül olabilir. F’nin öyküsü de anlatıldığı kadarıyla bu duruma uygundur. Eğer bir travma öyküsü olmasaydı F'nin yaşadığı şizoid yalnızlık bir çeşit his kaybı olabilirdi. His kaybı olsaydı eğer bu durum yalnızlıktan ziyade, daha çok soruna yol açacak bir tek başınalık olarak yorumlanabilirdi.

Şimdiye değin anlatılan kişilik bozukluklarında ortaya çıkan yalnızlığın dinamiğinde ağırlıklı olarak kalıtımsal eğilimler, farklı zamanlarda ve niteliklerde yaşanan erken çocukluk travmaları ve bu travmaların oluşturduğu zihinsel temsiller yer almaktadır. Kişilik bozukluklarında yalnızlığın problem olduğu diğer bozukluklar çekingen ve bağımlı kişilik bozukluklarıdır. Ancak bu iki bozuklukta G vakasında anlatılacağı gibi yalnızlığın niteliğini belirleyen şey temelde değersizlik duygusu gibi görünmektedir. 


\section{Çekingen ve Bağımlı Kişilik Bozukluğu}

“G, 27 yaşında, kadın, mimar, bir kamu kurumunda mimarlık yapmaktadır. Lisede ayrı odada yatamadığı ve annesiyle birlikte uyuduğu için psikiyatrik bir yardım almış. İlaç kullanmış. Ancak 6 ay kullanmasına rağmen ilacın bir faydasını görmediği için ilacı ve psikiyatra gitmeyi bırakmış. Çocukluğundan itibaren yalnızlık G'yi hep korkutmuş. Annenin eteğinden ayrılmayan bir çocukmuş. Anaokuluna ve ilköğretime başlaması çok sorun olmuş. Anneden ayrılmak istememiş. Uzun süre annesi okulda beklemiş. G tek başına hiçbir şey yapmak istememekte ve hiçbir şeyden zevk almamaktadır. Çok basit konularda bile (örn. İşe giderken ne giyeceği konusu) kendi başına karar verememektedir. Eğer buna mecbur kalırsa çok güçlük çekmektedir. İnsanlar onu yalnız bırakmasın diye hiçbir zaman kendi istediği şekilde davranmayıp sürekli diğer insanlara uygun şekilde davranmaktadır. Bu şekilde görünürde yalnız kalmamakta ancak düşüncelerini, duygularını ve taleplerini ifade etmediği için kendisini anlaşılmamış, önemsenmemiş ve yalnız hissetmektedir.”

Çekingen ve bağımlı kişilik bozukluğu (ÇKB, BKB) DSM-5 te C/kaygılı kümede yer alan bozukluklardan ikisidir. ÇKB tanısı sosyal fobide olduğu gibi eleştirilme, reddedilme ve kabul görmeme ihtimaline karşı aşırı duyarlı olan ve bu nedenle insanlarla ilişki kuramayan kişilere konur. Bu kişiler başkalarının kendileri hakkındaki düşünceleri ile aşırı meşguldürler. Bu nedenden dolayı farklı aktivitelere kolay kolay katılmazlar. BKB olan kişiler başkalarının fikrini almadan hareket edemezler. Yalnız kalma konusunda yoğun korkular yaşarlar ve başkalarının fikrini ve onayını alabilmek için hoş olmayan şeyler yaparlar. Sosyal fobiden farkı bu özelliklerin bir kişilik örüntüsü olması ve erken ergenlikten itibaren görülmeye başlamasıdır. Ancak bu üç bozukluk sıklıkla birlikte görülürler. BKB ve ÇKB olan kişilerin temelde kendilerine güvenleri yoktur. Tıpkı G'de olduğu gibi bu kişiler pasif bir şekilde nerede yaşayacaklarına, ne iş yapmaları gerektiğine, kiminle arkadaşlık edeceklerine vb. karar verme sorumluluğunu eşlerine ya da yakınlarına bırakırlar. Karşı tarafı ve onların onayını kaybetmekten korktukları için hatalı olduğunu bildiği halde onun fikrine katılırlar. Yalnız kalmaktan sürekli olarak korkarlar (DSM-5; Kring ve ark., 2014). Bu iki bozukluğun dışavurumu her ne kadar farklı olsa da Westen ve Shedler (2007) bu bozuklukların temel noktalarda çok sayıda ortak özellikler taşıdı̆̆ını, iki bozuklukta da depresif bir çekirdeğin bulunduğunu, bu nedenle birbirinden ayırmanın güç olduğunu belirtmişlerdir. Her iki bozuklukta da kişiler çok yoğun bir şekilde yetersizlik, başarısızlık ve değersizlik duyguları yaşarlar. İnsanların onların kusurlarını ve yetersizliklerini fark edip onları reddetmesinden veya terk etmesinden çok korkarlar. Bu yüzden kendilerini çok çaresiz ve umutsuz hissederler. Mevcut korkuları yüzünden asla kendileri olamazlar. Sadece bu korkularıyla baş etme stratejileri bir miktar farklıdır. Çekingen kişiler insanlardan kaçarak yetersizlik ve değersizlik duygularını maskelerken, bağımlı kişiler daha çok başkalarının onayını almadan 
hareket etmeyerek bununla baş ederler. ÇKB ve BKB'deki yalnızlık sosyal fobide hissedilen yalnızlığa benzerdir. Yani bu kişiler yalnız kalmak istemezler. Reddedilme ya da terkedilme korkuları yüzünden yalnız kalırlar. Etraflarında insan olsa bile yalnız hissederler. Çünkü korkuları yüzünden kendilerini saklamaktadır. ÇKB ve BKB'deki yalnızlık sosyal fobide hissedilen yalnızlıktan farklı olarak, sorunlu bir kişilik örüntüsünün yol açtığı yalnızlık olduğu için çok daha derin yaşanır ve daha depresif bir nitelik taşır.

\section{Sonuç}

Daha öncede değinildiği gibi, yapılan araştırmalar yalnız kalabilme kapasitesinin ruh sağlığıyla pozitif yönde doğrudan ilişkili olduğunu (Katz ve Buchholz, 1999; Larson, 1997; Larson ve Lee, 1996; Mushtaq ve ark. 2014), yalnızlığın objektif olarak tanımlanabilmesine rağmen oldukça sübjektif bir deneyim olduğunu (Perlman ve Peplau, 1984) ve çok boyutlu bir olgu olarak ele alınması gerektiğini (Horowitz, French, ve Anderson, 1982) ortaya çlkarmıştır.

$\mathrm{Bu}$ makalede, yardım almak amacıyla danışma merkezine başvuran vakalar üzerinden, psikolojik bozukluklarda yaşanan yalnızlı̆̆ın niteliksel özellikleri ve kökenleri tartışılmıştır. Bu sübjektif deneyimin niteliksel özelliklerini ve kökenlerini anlamak önemlidir. Çünkü kişinin tek başına kaldığında psikolojik bir sorun yaşamaması ve üretken olabilmesi yalnızlık deneyimlerinin niteliklerine bağlıdır. Eğer bir kişi tercih ettiğinde yalnız kalabiliyorsa, kendi istediğinde bir sosyal grubun içine girebiliyorsa, diğer insanlarla onaylayıcı ve destekleyici bir ilişkiyi başlatıp sürdürebiliyorsa, öfke ve korku gibi duygularını etkili bir şekilde düzenleyebiliyorsa, yalnız kaldığında bu yalnızlık üretken bir sürece dönüşebilir. Aksi halde bu süreç oldukça yıkıcı boyutlara taşınabilir (Rubin, 2013). Problemli bir sürece dönüşen yalnızlığın niteliklerine pek çok durum etki etmektedir. Şizoid kişilik bozukluğu gibi bazı bozukluklarda ağırlıklı olarak kalıtımsal eğilimler yalnızlığı ortaya çıkarırken, borderline kişilik bozukluğu gibi bazı bozukluklarda erken çocukluk travmaları yalnızlıkla ilişkili gibi görünmektedir. Bu nedenler kişinin yaşadığı yalnızlığın niteliğini de değiştirmektedir. Görünürde yukarıda sunulan vaka öykülerinde anlatılan bozukluklara sahip kişilerin hepsi yalnızlık hissetmektedir. Ancak daha derinden bakıldığında yaşanan yalnızlığın sübjektif bir deneyim olduğu ve birbirlerinden çok farklı olduğu görülecektir. Dolayısıyla bu kişilerin yalnızlıkla baş etme süreci ile çalışılırken farklı müdahale yöntemlerine ihtiyaç vardır. Örneğin; sosyal kaygısı olan bir hastayla çalışırken değerlendirilme kayısına odaklanmak ve sürekli olarak diğerlerinin zihnini okumamayı öğretmek gerekirken, otizmi olan bir hastayla çalışırken gerektiğinde diğerlerinin niyetlerini anlamaya çalışmayı öğretmek gerekir. Yani psikolojik bozukluklarda yaşanan yalnızlı̆̆ın 
oluşma sürecini ve niteliğini bilmek, bu alanda çalışan kişilerin hastanın ihtiyacını ona uygun ve doğru bir şekilde karşılamasını sağlayacak müdahale yöntemlerini belirlemesine ciddi katkı sağlayacaktır. Ayrıca gelişimsel süreçte herhangi bir nedenle yalnızlık yaşayan çocuklar için yapılacak olan anne babalara ve okulda çalışan eğitimcilere yönelik önleyici programların içeriğini hazırlarken, bu çocuklarda yaşanan yalnızlı̆̆ın kökenlerini ve niteliğini dikkate almak çok daha etkili programların ortaya çıkmasını sağlayacaktır.

$\mathrm{Bu}$ araştırmanın bazı sınırlılıkları vardır. Araştırmada psikolojik bozukluklarda yaşanan yalnızlığın niteliği vaka sunumları yöntemiyle tartışılmıştır. Bu yöntem aracılı̆̆ıyla yapılan araştırmaların güvenirliliği ve geçerliliği daha düşüktür. Bu nedenle yapılacak araştırmalarda, makalede tartışılan sübjektif deneyimin nedenlerine ve niteliksel farklılıklarına daha fazla yer ayırmak ve bu farklılıkları işevuruk hale getirip niceliksel araştırma yöntemleriyle değerlendirmek önemlidir. 


\section{Kaynakça}

Akbağ, M. ve İmamoğlu, S. E. (2010). The prediction of gender and attachment styles on shame, guilt, and loneliness. Educational Sciences: Theory and Practice, 10, 669-682.

American Psychiatric Association (2013). Diagnostic and statistical manual of mental disorders, $5^{\text {th }}$ ed., Washington, DC: Author.

Attwood, T. (2000). Strategies for improving the social integration of children with Asperger syndrome. Autism, 4, 85-100. doi:10.1177/1362361300004001006.

Baumeister R. F. ve Leary, M. R. (1995). The need to belong: Desire for interpersonal attachments as a fundamental human motivation. Psychological Bulletin, 117, 3, 497-529.

Bauminger, N. ve Kasari, C. (2000). Loneliness and friendship in high-functioning children with autism. Child Development, 71, 447-456. doi:10.1111/1467-8624.00156.

Blatt, S. J., Auerbach, J. S. ve Levy, K. N. (1997). Mental Representations in Personality Development, Psychopathology, and the Therapeutic Process. Review of General Psychology, 1(4), 351-374.

Bowlby, J. (1973). Attachment and loss: Vol. 1. Attachment. New York: Basic Books.

Brown, L. H., Silvia, P. J., Myin-Germeys, I. ve Kwapil, T. R. (2007). When the need to belong goes wrong: the expression of social anhedonia and social anxiety in daily life. 778-782

Cacioppo, J. T., ve Patrick, B. (2008). Loneliness: Human nature and the need for social connection. New York: W. W. Norton.

Coplan, R. J. ve Bowker, J. C. (2013). All Alone Multiple Perspectives on the Study of Solitude. İçinde R. J. Coplan ve J. C. Bowker (Ed.), Handbook of Solitude: Psychological Perspectives on Social Isolation, Social Withdrawal, and Being Alone (pp. 3-13). Somerset: Wiley-Blackwell.

Davison, G. C. ve Neale, J. M. (1997). Anormal Psikolojisi. Ankara: Türk Psikologlar Derneği Yayınları.

DeWall, C. N. ve Bushman, B. J. (2011). Social acceptance and rejection: the sweet and the bitter. Current Directions in Psychological Science, 20, 4, 256-260.

Duy, B. (2003). Bilişsel-davranışçı yaklaşıma dayalı grupla psikolojik danışmanın yalnızlık ve fonksiyonel olmayan tutumlar üzerine etkisi. Yayınlanmamış Doktora Tezi, Ankara Üniversitesi Ĕ̆itim Bilimleri Enstitüsü, Ankara.

Eisenberger, N. I. (2012). The neural bases of social pain: Evidence for shared representations with physical pain. Psychosomatic Medicine, 74, 2, 126-135. doi:10.1097/PSY.obo13e3182464dd1.

Ernst, J. M. ve Cacioppo, J. T. (1999). Lonely hearts: Psychological perspectives on loneliness. Applied \& Preventive Psychology, 8, 1-22.

Fairbairn, W. R. D. (1952). Psychoanalytic Studies of the Personality. London: Routledge and Kegan Paul.

Fromm-Reichmann, F. (1959). Loneliness. Psychiatry, 22, 1-15.

Griffin, J. (2017). The Lonely Society. Erişim: https://www.mentalhealth.org.uk/

Gunderson, J. G. (1996). The borderline patient's intolerance of aloneness: insecure attachments and therapist availability. The American Journal of Psychiatry, 153, 6,752-8.

Heinrich, L. M. ve Gullone, E. (2006). The clinical significance of loneliness: A literature review. Clinical Psychology Review, 26, 695-718 
Horowitz, L. M., French, R. D. ve Anderson, C. A. (1982). The prototype of a lonely person. İçinde, L. A. Peplau ve D. Perlman (Ed.), Loneliness: A Sourcebook of Current Theory, Research and Therapy (pp. 183-205). New York: Wiley.

İlhan, (2012). Üniversite öğrencilerinde yalnızlık: cinsiyet rolleri ve bağlanma stillerinin yalnızlı̆̆ yordama güçleri. Kuram ve Uygulamada Ĕ̆itim Bilimleri, 12, 4, 2377-2396.

Karnick, P. M. (2005). Feeling lonely: Theoretical perspectives. nursing science quarterly, 18, 1, 7-12. doi: $10.1177 / 0894318404272483$

Kasari, C. ve Sterling, L. (2013). Loneliness and social isolation in children with autism spectrum disorder. İçinde, R. J. Coplan ve J. C. Bowker (Ed.), Handbook of Solitude: Psychological Perspectives on Social Isolation, Social Withdrawal, and Being Alone (pp. 409-426). Somerset: Wiley-Blackwell.

Katz, J. C.,ve Buchholz, E. S. (1999)."I did it myself”: The necessity of solo play for preschoolers. Child Development, 55, 2212-2225.

Kernberg, O. F. (1975). Borderline Conditions and Pathological Narcissism. New York: Aronson.

Kernberg, O. F. (1984). Severe Personality Disorders: Psychotherapeutic Strategies. New Haven, CT: Yale University Press.

Klein, M. (1975). On the sense of loneliness. In M. Klein (Ed.), Envy and gratitude and other Works, 1946-1963. The writings of Melanie Klein (Vol. 3, pp. 300-313). New York: Free Press. (Original paper published 1963).

Klonsky, E. D. (2008). What is emptiness? Clarifying the 7 th criterion for borderline personality disorder. Journal of Personality Disorders, 22, 4, 418-426.

Kohut, H. (1971). The Analysis of the Self: A Systematic Approach to the Psychoanalytic Treatment of Narcissistic Personality Disorders. New York: International Universities Press.

Kring, A. M., Johnson, S. L., Davison, G. C. ve Neale, J. M. (2014). Abnormal psychology, 12th edition dsm-5 update. John Wiley \& Sons, Inc. (ISBN 978-1-1180-1849-1)

Kupersmith, J. B., Sigda, K. B., Sedikides, C., ve Voegler, M. E. (1999). Social self-discrepancy theory and loneliness during childhood and adolescence. İçinde, K. J. Rotenberg, ve S. Hymel, (Ed.). Loneliness in Childhood and Adolescence (pp. 263-279). New York: Cambridge University Press.

Kwapil, T. R. Silvia, P. J. ve Barrantes-Vidal, N. (2013). Social anhedonia and solitude. İçinde, R. J. Coplan ve J. C. Bowker (Ed.), Handbook of Solitude: Psychological Perspectives on Social Isolation, Social Withdrawal, and Being Alone (pp. 371-390). Somerset: Wiley-Blackwell.

Larson, R. W. (1997). The emergence of solitude as a constructive domain of experience in early adolescence. Child Development, 68, 1, 80-93

Larson, R. W. ve Lee, M. (1996). The Capacity to Be Alone as a Stress Buffer. The Journal of Social Psychology, 136, 5-16.

Long, C. R. ve Averill, J.R. (2003). Solitude: An exploration of benefits of being alone, journal for the theory of social behavior, 33, 1, 21-44. doi: 10.1111/1468-5914.00204.

MacDonald, G. ve Leary, M. R. (2005). Why does social exclusion hurt? The relationship between social and physical pain. Psychological Bulletin, 131, 2, 202-223

Mahler, M., Pine, F. ve Bergman A. (1975). The Psychological Birth of the Human Infant: Symbiosis and Individuation. New York: Basic Books, Inc.

Martens, W. H. J. (2010). Schizoid personality disorder linked to unbearable and inescapable loneliness. European Journal of Psychiatry, 24, 38-45. 
McGraw, J. G. (2010). Intimacy and Isolation. Amsterdam, New York: Value Inquiry Book Series/Philosophy and Psychology.

McGraw, J. G. (2012). Personality Disorders and States of Aloneness. New York: Value Inquiry Book Series/Philosophy and Psychology.

Meehan, K. B., Levy, K. N., Temes, C. M. ve Detrixhe, J. (2013). Solitude and personality disorders. İçinde, R. J. Coplan, ve J. Bowker (Ed.), A Handbook of Solitude: Psychological Perspectives on Social Isolation, Social Withdrawal, and Being Alone (pp. 427-444). Somerset: WileyBlackwell.

Millon, T. ve Davis, R. D. (1996). Schizoid personality disorders: The asocial pattern. İçinde, T. Millon ve R. D. Davis (Ed.), Disorders of personality DSM-IV TM and Beyond. New York: Wiley \& Sons.

Mushtaq, R., Shoib, S. Shah, T., ve Mushtaq, S. (2014). Relationship between loneliness, psychiatric disorders and physical health? A review on the psychological aspects of loneliness. Journal of Clinical and Diagnostic Research, 8, 9, 1-4

Nietzsche, F. W. (1997). Böyle Buyurdu Zerdüşt (T. Oflazoğlu, Çev). İstanbul: Cem Yayınevi.

Peplau, L. A. ve Perlman, D. (1982). Perspectives on loneliness. İçinde, L. A. Peplau ve D. Perlman (Ed.), Loneliness: A Sourcebook of Current Theory, Research And Therapy. New York: WileyInterscience.

Perlman, D. ve Peplau, L. A. (1984) Loneliness research: survey of empirical findings. İçinde, L.A. Peplau ve S.E. Goldston (Eds) Preventing the Harmful Consequences of Severe and Persistent Loneliness (pp. 13-46). Washington, DC, US Government Printing Office.

Piaget, J. (1932). The Language and Thought of the Child. London, New York: Routledge \& Kegan Paul Ltd.

Rubin, K. H. (2013). Foreword, on solitude, withdrawal, and social isolation. In R. J. Coplan ve J. C. Bowker (Ed.), Handbook of Solitude: Psychological Perspectives on Social Isolation, Social Withdrawal, and Being Alone (pp. xii-xviii). Somerset, Wiley-Blackwell.

Shevlin, M., McElroy, E. ve Murphy, J. (2015). Loneliness mediates the relationship between childhood trauma and adult psychopathology: evidence from the adult psychiatric morbidity survey. Social Psychiatry and Psychiatric Epidemiology, 50, 59-601. doi: 10.1007/s00127014-0951-8

Silvia, P. J. ve Kwapil, T. R. (2011). Aberrant asociality: how individual differences in social anhedonia illuminate the need to belong. Journal of Personality, 79, 1315-1332

Sullivan, H. S. (1953). The Interpersonal Theory of Psychiatry. New York: Norton.

Weeks, M. S. ve Asher, S. R. (2012). Loneliness in childhood: Toward the next generation of assessment and research. In J. B. Benson (Eds.), Advances in Child Development and Behavior, Volume 42. New York: Academic Press

Weiss, R. S. (1973). Loneliness: The Experience of Emotional and Social Isolation. Cambridge, MA: MIT Press.

Westen, D. ve Shedler, J. (2007). Personality diagnosis with the shedler-westen assessment procedure (SWAP): Integrating clinical and statistical measurement and prediction. Journal of Abnormal Psychology, 116, 4, 810-822

White, S. W. ve Roberson-Nay, R. (2009). Anxiety, social deficits, and loneliness in youth with autism spectrum disorders. Journal of Autism and Developmental Disorders, 39, 7, 1006-1013. doi:10.1007/s10803-009-0713-8 
Winnicott, D. W., (1965). The Maturational Processes and the Facilitating Environment, Studies in the Theory of Emotional Development. London: The Hogarth Press and the Institute of Psycho-Analysis.

Yılmaz, E. ve Karaca, F. (2008). Üniversite öğrencilerinin sosyal destek ve yalnızlık düzeylerinin incelenmesi. Genel Trp Dergisi, 18, 2, 71-79. 


\section{Loneliness as a Clinical Fact: Loneliness and Psychological Disorders}

\section{Summary}

Loneliness is becoming more and more a problem every day due to rapidly changing environmental and social conditions in the current century. Research in this area has shown that long-term loneliness is highly associated with such psychological disorders as generalized anxiety disorder, obsessive-compulsive disorder, panic disorder, depression, and eating disorders as well as such health-related problems as, alcohol use and cardiovascular disorders (Griffin, 2016; Heinrich \& Gullone, 2006; Mushtaq, Shoib, Shah \& Mushtaq, 2014; Shevlin, McElroy \& Murphy, 2015). Studies in clinical psychology have shown that psychological disorders are directly related to loneliness, but very few studies have addressed the qualitative difference in loneliness occurring in different clinical disorders.

This lack of attention to qualitative state of loneliness also appears in research conducted in Turkey. The focus was mostly on establishing cause-effect relations or developing intervention models on loneliness. There are research reports that address the relationship between perceived level of social support and loneliness among university students (Yılmaz, Yılmaz \& Karaca, 2008); effect of gender and attachment style on shame, guilt and loneliness (Akbağ \& İmamoğlu, 2010); loneliness in university students: gender roles and loneliness predictors of attachment styles (İlhan, 2012), and the effects of psychological counseling with cognitive-behavioral approach-based groups on loneliness and non-functional attitudes (Duy, 2003). Yet, there is no study on the singularity and quality of loneliness experienced in psychological disorders.

The aim of this study was to reveal qualitative differences in loneliness experienced in different psychopathologies including, but not all, schizophrenia, social phobia, and autism. For this purpose, experiences and narrations of the clients were analyzed under the light of the research literature on the subject.

\section{Method}

Psychopathologies co-occurring with high levels of loneliness that poses as a significant issue that needs to be addressed comprised the study. Eight different psychological disorders including schizophrenia, social anxiety disorder (social phobia), autism, borderline personality disorder, narcissistic personality disorder, schizoid personality disorder, avoidant personality disorder, and dependent personality disorder were explored in the study. Case samples presented in the study were selected among the clients in a 
counseling center serving women only and run by the municipality. The researcher worked as a clinical psychologist and institutional manager at the center. The clients were informed about the study and measures that would be taken to keep their identity confidential, and their consents were obtained. In order to protect the identity of the participants, code letters replaced the names of the participants and any information that would reveal their identities was omitted.

\section{Case Presentations and Conclusion}

Eight different cases were presented in this article. Each case is an example of a different psychological disorder. Case A is schizophrenia patient, case B is social anxiety disorder patient, case $\mathrm{C}$ is autism spectrum disorder patient. Loneliness appears to be a major issue that needs to be dealt with in these three disorders. Analysis of the cases revealed that for some cases loneliness is a preference while for others it is not. For example, for the patient with schizophrenia loneliness seems to be a personal preference resulting from social anhedonia. For the patient with social anxiety disorder loneliness is not something desirable but driven by an anxiety over social judgments and rejection. Similarly, the individual with autism viewed loneliness as an undesirable state that is largely caused by lack of social skills. However, the literature shows that although some people with autism prefer to be alone for many it is not their personal choice.

In this article, cases of personality disorders for which loneliness is considered to be a serious symptom were also presented including borderline personality disorder in case $\mathrm{D}$, narcissistic personality disorder in case E, schizoid personality disorder in case $\mathrm{F}$, and dependent and avoidant personality disorder in case G. The loneliness in case D was caused by the traumas experienced mostly in early childhood. It is presumed that early childhood trauma leads to the imaginary level representation of the others in person's mind. Loneliness or intolerance to loneliness in case $\mathrm{B}$, the person with borderline personality disorder, seemed to be related to an absence of the image of others in mind and pain created by that absence. Like the case in borderline personality disorder, in case E, the person with narcissistic personality disorder, loneliness was formed because of problematic early childhood experiences. However, rather than an absence of mental representations of others, it was the presence of opposite and dispersed self-representations that caused loneliness. In case $\mathrm{F}$ with schizoid personality disorder, loneliness seems to be a protective capsule developed against a threatening world. The avoidant personality disorder described in case G, and loneliness in the case with dependent personality disorder are similar to the loneliness experienced in case $\mathrm{B}$, the social anxiety case. These patients did not want to be alone and 
could easily resolve implicit or explicit messages in social relationships. However, their lack of self- confidence and high levels of social anxiety made it difficult for them to establish healthy relationships.

Understanding the source and quality of loneliness experienced in psychological disorders is very important in prevention of psychological disorders. Therefore, further research is needed to explore in more detail the causes and qualitative differences of the subjective experience discussed in the article. 